\title{
Anal Leiomyosarcoma
}

National Cancer Institute

\section{Source}

National Cancer Institute. Anal Leiomyosarcoma. NCI Thesaurus. Code C5599.

An aggressive malignant smooth muscle neoplasm, arising from the anus. It is characterized by a proliferation of neoplastic spindle cells. 